\title{
HIGH SKIN MELANIN CONTENT, VITAMIN D DEFICIENCY AND IMMUNITY: POTENTIAL INTERFERENCE FOR SEVERITY OF COVID-19
}

\author{
MUHAMMAD TOREQUL ISLAM ${ }^{1,2 \#}$, BAHARE SALEHI ${ }^{3 \#}$, OANA KARAMPELAS ${ }^{4 \#}$, JAVAD \\ SHARIFI-RAD ${ }^{5,6 *}$, ANCA OANA DOCEA ${ }^{7}$, MIQUEL MARTORELL $^{8}$, DANIELA CALINA $^{9}$ \\ ${ }^{1}$ Laboratory of Theoretical and Computational Biophysics, Ton Duc Thang University, Ho Chi Minh City, Vietnam \\ ${ }^{2}$ Faculty of Pharmacy, Ton Duc Thang University, Ho Chi Minh City, Vietnam \\ ${ }^{3}$ Medical Ethics and Law Research Centre, Shahid Beheshti University of Medical Sciences, Tehran, Iran \\ ${ }^{4}$ Department of Pharmaceutical Technology and Biopharmaceutics, "Carol Davila" University of Medicine and Pharmacy, \\ 020956, Bucharest, Romania \\ ${ }^{5}$ Facultad de Medicina, Universidad del Azuay, Cuenca, Ecuador \\ ${ }^{6}$ Phytochemistry Research Center, Shahid Beheshti University of Medical Sciences, Tehran, Iran \\ ${ }^{7}$ Department of Toxicology, University of Medicine and Pharmacy of Craiova, 200349, Craiova, Romania \\ ${ }^{8}$ Department of Nutrition and Dietetics, Faculty of Pharmacy, and Centre for Healthy Living, University of Concepción, \\ 4070386 Concepción, Chile \\ ${ }^{9}$ Department of Clinical Pharmacy, University of Medicine and Pharmacy of Craiova, 200349. Craiova, Romania
}

*corresponding author: javad.sharifirad@gmail.com

${ }^{\#}$ Authors with equal contribution.

Manuscript received: June 2020

\begin{abstract}
Due to the strong immunomodulatory effects, vitamin D (Vit-D) may be an option in COVID-19 disease. The skin pigment melanin has the photoprotective capacity, by inhibiting the synthesis of Vit-D in human. Dark skin contains a high level of melanin, which inhibits vit-D synthesis, leading to deficiency of this vitamin in certain people worldwide. It has been reported that the angiotensin II stimulates melanogenesis process. The SARS-CoV-2 uses the ACE2 receptor for the entrance into the human lung epithelial cells. Therefore, there is an interconnection between the ACE2, angiotensin II, melanogenesis and Vit-D levels in our body. An upregulation of angiotensin II is inversely co-related to the Vit-D synthesis in human. Taken together, SARS-CoV-2 may rule over the peoples having high skin melanin contents and its consequence of Vit-D deficiency. This review aims to highlight a correlation between skin melanin content, Vit-D status, immunity and the potential effects on SARS-CoV-2 prevalence in COVID-19 patients. As a novelty of this review, clinical trials on Vit-D aiming to fight against SARS-CoV-2 related pathological conditions or comorbidities in COVID-19 were included. The results of the analysed data showed that there is scientific evidence that a potential synergistic treatment with Vit-D could reduce the risk of SARS-CoV-2 infection and COVID-19 deaths.
\end{abstract}

\section{Rezumat}

Datorită efectelor imunomodulatoare puternice, vitamina D (Vit-D) poate fi o opțiune în tratamentul COVID-19. Melanina pigmentară are capacitate fotoprotectoare, inhibând astfel sinteza de Vit-D la om. Pielea închisă la culoare conține un nivel ridicat de melanină, care inhibă sinteza Vit-D, ducând la deficitul acestei vitamine la anumite persoane din întreaga lume. S-a raportat că angiotensina II stimulează procesul de melanogeneză. SARS-CoV-2 folosește receptorul ACE2 pentru intrarea în celulele epiteliale pulmonare umane. Prin urmare, există o interconectare între nivelurile ACE2, angiotensină II, melanogeneză și Vit-D în organismul uman. Reglarea activității angiotensinei II este invers corelată cu sinteza de Vit-D la om. SARS-CoV-2 poate infecta persoanele cu nivel ridicat de melanină și deficit de Vit-D. Acest studiu teoretic își propune să evidențieze o corelație între conținutul de melanină al pielii, statusul Vit-D, imunitatea și efectele potențiale asupra prevalenței SARS-CoV-2. $\mathrm{Ca}$ o noutate a acestui studiu, au fost incluse date clinice referitoare la Vit-D care raportează efectele asupra infecției cu SARSCoV-2. Rezultatele datelor analizate au arătat că există dovezi ştiinţifice pentru un potențial tratament sinergic cu Vit-D în vederea reducerii riscului de infecție cu SARS-CoV-2 și a deceselor cauzate de COVID-19.

Keywords: SARS-CoV-2, immunity, melanin, vitamin D, cytokines storm, COVID-19 severity

\section{Introduction}

SARS-CoV-2 (severe acute respiratory syndrome coronavirus 2) is a new coronavirus, first identified in December 2019 in an outbreak of pneumonia in China (Wuhan City, Hubei Province), which has not been previously identified in humans. It belongs to the Coronaviridae family, belonging to the same family as the viruses that cause severe acute respiratory syndrome (SARS) and middle-east respiratory syndrome 
(MERS) and seems to have epidemiological characteristics similar to them [31].

Epidemiological data to date suggest that COVID-19 disease has a fatality rate several times higher than that of seasonal influenza. The elderly and people with underlying medical comorbidities, such as cardiovascular disease, diabetes, chronic lung disease, chronic kidney disease, obesity, high blood pressure, or cancer, have a much higher mortality rate than healthy young adults $[18,38]$. The underlying causes of this condition are not known but may be caused by an impaired response to interferon and disordered inflammatory reactions, as observed with other coronavirus infections, such as SARS and MERS [36, 71, 117]. Although many classes of drugs have been tried so far, with the exception of remdesivir, no drugs have been officially approved so far $[8,114]$. Researchers around the world have been working to get a vaccine in record time, but so far no vaccine has been yet approved for manufacturing $[15,17]$. In addition, due to this accelerated process of obtaining an effective vaccine, there have been multiple controversies regarding human studies and their safety $[16,60]$.

Three central pathological processes lead to multiorgan failure and death in COVID-19 [125]: i) Hyperinflammation ("cytokine storm"): a disordered immune system in which cells infiltrate and affect several organs, namely the lungs, kidneys and heart. It is now widely accepted that SARS-CoV-2 causes aberrant activation of T lymphocytes and macrophages, resulting in a "cytokine storm"; ii) Hypercoagulability (increased clotting): the disordered immune system damages the endothelium and activates blood clotting, causing the formation of micro and macro blood clots. These blood clots affect blood flow; iii) Severe hypoxemia (low blood oxygen levels): inflammation of the lungs caused by a cytokine storm, along with micro thrombosis in the pulmonary circulation, which severely affects oxygen uptake, leading to insufficient oxygenation. A study conducted by an international team of researchers reveals potential therapeutic mechanisms and targets for COVID-19 disease [105]. The results indicate that the innate immune system is severely disrupted by SARS-CoV-2 infection. COVID-19 is a global crisis and yet there are still large knowledge gaps about human immunity to SARS-CoV-2. Understanding the immunological mechanisms underlying the various clinical presentations of COVID-19 disease is a critical step in designing rational therapeutic strategies [117] including potential vaccines against SARS-CoV-2 [15].

\section{Methodology}

A comprehensive search of the literature was performed in the following PubMed and Web of Science databases using the following keywords: immunity, SARS-CoV2, melanin, vitamin $\mathrm{D}$, mechanisms, viral respiratory diseases. The inclusion criteria for the researched articles were clinical trials on the correlation between melanin, Vit-D, immunity and viral respiratory infections, including those with SARS-CoV-2. The exclusion criteria were: studies that also included homoeopathic preparations, abstracts, papers published in languages other than English.

\section{The immune system, severely affected by the attack of SARS-CoV-2 infection}

Most patients with a severe form of COVID-19 have elevated levels of proinflammatory cytokines, including interleukin (IL)-6, IL-1 $\beta$, as well as plasma monocyte chemotactic protein-1 (MCP-1), interferongamma-inducible protein-10 (IP-10), and granulocyte colony-stimulating factor (G-CSF). It has been proposed that high levels of proinflammatory cytokines may lead to shock as well as respiratory failure or multiple organ failure and several studies to evaluate inflammatory mediators are still ongoing [119].

In some patients with COVID-19, the expression of proinflammatory cytokines by myeloid cells decreased, whereas there were elevated plasma levels of inflammatory mediators, including the extracellular newly identified receptor for advanced glycation endproducts binding protein (EN-RAGE), tumour necrosis factor superfamily member 14 (TNFSF14), and oncostatin-M, which correlated with disease severity and bacterial products increased in human plasma. However, little is known about the immunological mechanisms underlying the severity of COVID-19 and the extent to which they differ from the immune response to other respiratory viruses. Moreover, the answer to the question of whether individuals in different parts of the world respond differently to SARS-CoV-2 remains unknown [106].

Recent reports suggest that patients with COVID-19 are characterized by lymphopenia and an increased number of neutrophils. In the current study, scientists used a biological systems approach to analyse the immune response in 76 patients with COVID-19 and a control group of the same sex and age (approximately 69 years) of two geographically distant cohorts [98]. Thus, the research team followed a systems biologybased approach to determine the immune responses of people affected by COVID- 19 .

Analysis of mass cytometry of peripheral blood leukocytes from two independent cohorts, from Hong Kong and Atlanta, revealed some common features of immune responses induced by SARS-CoV-2 infection. There has been a striking and prolonged increase in the frequencies of plasmablasts and CD8 effector T cells in peripheral blood, consistent with other recent studies. Also, effector T cells continued to grow until 40 days after the onset of symptoms. Other studies have shown that SARS-CoV-2 infection induces depletion and apoptosis (cell death) in T cells [9]. 
In addition to plasmacytoid-affected interferon-alpha $(\mathrm{IFN}-\alpha)$ production, there was a marked decrease in the proinflammatory cytokines IL- 6 , tumour necrosis factor-alpha (TNF- $\alpha$ ) and IL- $1 \beta$ produced by monocytes and myeloid cells. These results suggest an innate impaired response in leukocytes in patients with COVID-19 [94].

\section{Proinflammatory cytokines associated with bacteria of pulmonary origin}

Multiples analysis of plasma cytokines revealed increased levels of several proinflammatory cytokines, as previously observed and a strong association of inflammatory mediators EN-RAGE, TNFSF14 and oncostatin-M with the clinical severity of the disease. The proinflammatory cytokines observed in plasma probably come from cells in lung tissue, rather than from cells in peripheral blood. Taken together, plasma cytokine-related data with mass cytometry data can be used to construct an immune profile distinguishing between the severe and moderate form of COVID19 [25].

In summary, this study suggests that SARS-CoV-2 infection results in a spatial division in the innate immune response, characterized by the suppression of the innate immunity, in the face of reported proinflammatory reactions to the lung. Moreover, there is a temporal change in the cytokine response from an early but transient, type 1 IFN response to a proinflammatory response in later and more severe stages, similar to that seen with other diseases, such as influenza [30].

Surprisingly, there were increased levels of bacterial DNA and lipopolysaccharides (constituents of the cell walls of gram-negative bacteria) in plasma, which were positively correlated with plasma levels of EN-RAGE, TNFSF14, oncostatin-M, and IL-6. This suggests a role for bacterial products, perhaps of pulmonary origin, in increasing the production of inflammatory cytokines in severe COVID-19 disease. The biological consequence of the affected innate immune response in peripheral blood is not known. Still, it may reflect a homeostatic mechanism to prevent systemic hyperactivation in the face of tissue inflammation. Finally, these results highlight molecules such as EN-RAGE or TNFSF14 and their receptors, which could be a therapeutic target against COVID19 disease.

Approximately $80 \%$ people of the world are pigmented [48]. Among the four significant pigments, melanin and haemoglobin are known skin colour contributors in human [67]. Melanin (brown or black (eumelanin), red or yellow (pheomelanin), dark pigment (neuromelanin) is a biopolymer complex mixture of quinone/ indolequinone derivatives [103]. The elliptical melanosomes produce eumelanin, while rounded melanosomes produce the pheomelanin in human
$[13,112]$. The peoples having dark skin contain a high level of melanin than lighter skin peoples. Melanin protects our skin from the harmful effects of ultraviolet (UV) radiation [1].

Melanocytes present in the basal layer of the epidermis are responsible for melanin production [48]. Among the natural sunlight (e.g., UVA and UVB) UVB is the most biologically active form, which at wavelength 290 - 315 nm synthesizes Vit-D in our skin (Figure 1). Tyrosinase catalyses the hydroxylation of tyrosine and oxidation of dopa, resulting in the formation of melanin through a free radical coupling pathway [121] (Figure 2).

On the other hand, vitamin D (Vit-D) is a prohormone that facilitates calcium absorption from our gut. The deficiency of it causes rickets in children and osteomalacia in older people $[14,68]$. Vit-D3 (also called calcitriol), a fat-soluble vitamin, which is mostly found in fish, eggs, liver, butter and margarine [104]. In the liver, Vit-D3 converts into 25-hydroxy-Vit-D3 through hydroxylation, which transfers into 1- $\alpha, 25$ dihydroxy-Vit-D3 (calcitriol) in the kidneys [13]. However, left un-exposure of the next day Vit-D3 can't enter into the bloodstream due to the rapid degradation into suprasterol1, suprasternal and 5,6 trans-Vit-D3 (biologically inactive forms) [51].

Solar radiation triggers a strong seasonal production of Vit-D in the skin; Vit-D deficiency is common in winter, and activated Vit-D, 1,25 (OH) 2D, a steroid hormone, has profound effects on human immunity [108]. Vitamin 1,25 (OH) 2D acts as a modulator of the immune system, preventing the excessive expression of inflammatory cytokines and increasing the potential for "oxidative explosion" of macrophages. Perhaps most important is the drastic stimulation of the expression of strong antimicrobial peptides, which exist in neutrophils, monocytes, natural killer cells and epithelial cells that cover the airways, where they play an essential role in protecting the lungs from infection. Volunteers inoculated with live attenuated influenza virus are more likely to develop fever and serological evidence of an immune response in winter. Vit-D deficiency predisposes children to respiratory infections. UV radiation (either from artificial sources or sunlight) reduces the incidence of viral respiratory infections, as does cod liver oil (which contains VitD). An interventional study showed that Vit-D reduces the incidence of respiratory infections in children [127].

The recommended daily amount is $600 \mathrm{IU}$ per day, increasing to $800 \mathrm{IU} /$ day in those over 71 years [40]. Vit-D supplements should be used when dietary and lifestyle recommendations (sunlight) cannot be implemented [110]. Increased intake of fortified foods or sun exposure is not recommended. It appears that up to 4,000 IU of Vit-D3/day are without significant side effects and increase serum $25(\mathrm{OH}) \mathrm{D}$ levels at normal-high physiological concentrations [39]. 
FARMACIA, 2020, Vol. 68, 6

The link between Vit-D and severity of COVID-19 disease has been enhanced by a recent study which analysed the data of all patients at Vienna General Hospital between 1991 and 2011, whose $25(\mathrm{OH}) \mathrm{D}$ levels were measured, a total of 78,581 patients, with the Austrian National Death Registry [113]. In those 20 years, 11,877 deaths were observed, and the death risk rate was calculated. Values of $25(\mathrm{OH}) \mathrm{D} \leq 10$ $\mathrm{nmol} / \mathrm{L}$ were associated with a risk of death two to three times higher in those under 75 years of age, while values of $25(\mathrm{OH}) \mathrm{D} \geq 90$ were associated $\mathrm{nmol} / \mathrm{L}$ at a $40 \%$ lower risk of death in those under 75 years of age compared to the $50 \mathrm{nmol} / \mathrm{L}$ reference value. In terms of mortality from specific causes, they found that the strongest association between low
Vit-D and the cause of death was for diabetes with a 4 times higher risk, and for infectious diseases and other diseases with a 2 times higher risk, even if not for cancer or cardiovascular disease $[42,113]$.

According to the scientific reports, the exposure time of the light skin peoples is between 20 and 30 minutes, while it is $2-10$ fold larger for the dark skin peoples for 2 - 3 times in a week to produce around 20,000 IU of Vit-D3 [95]. An increasing in melanin level in the skin reduces the production of Vit-D3 of the dark skin peoples of high latitude [65]. 7-dehydrocholesterol is abundantly in the epidermis that absorbs UVB and induces photoisomerization to a compound pre-vit-D. Skin pigmentation due to melanin deposition affects Vit-D3 synthesis.

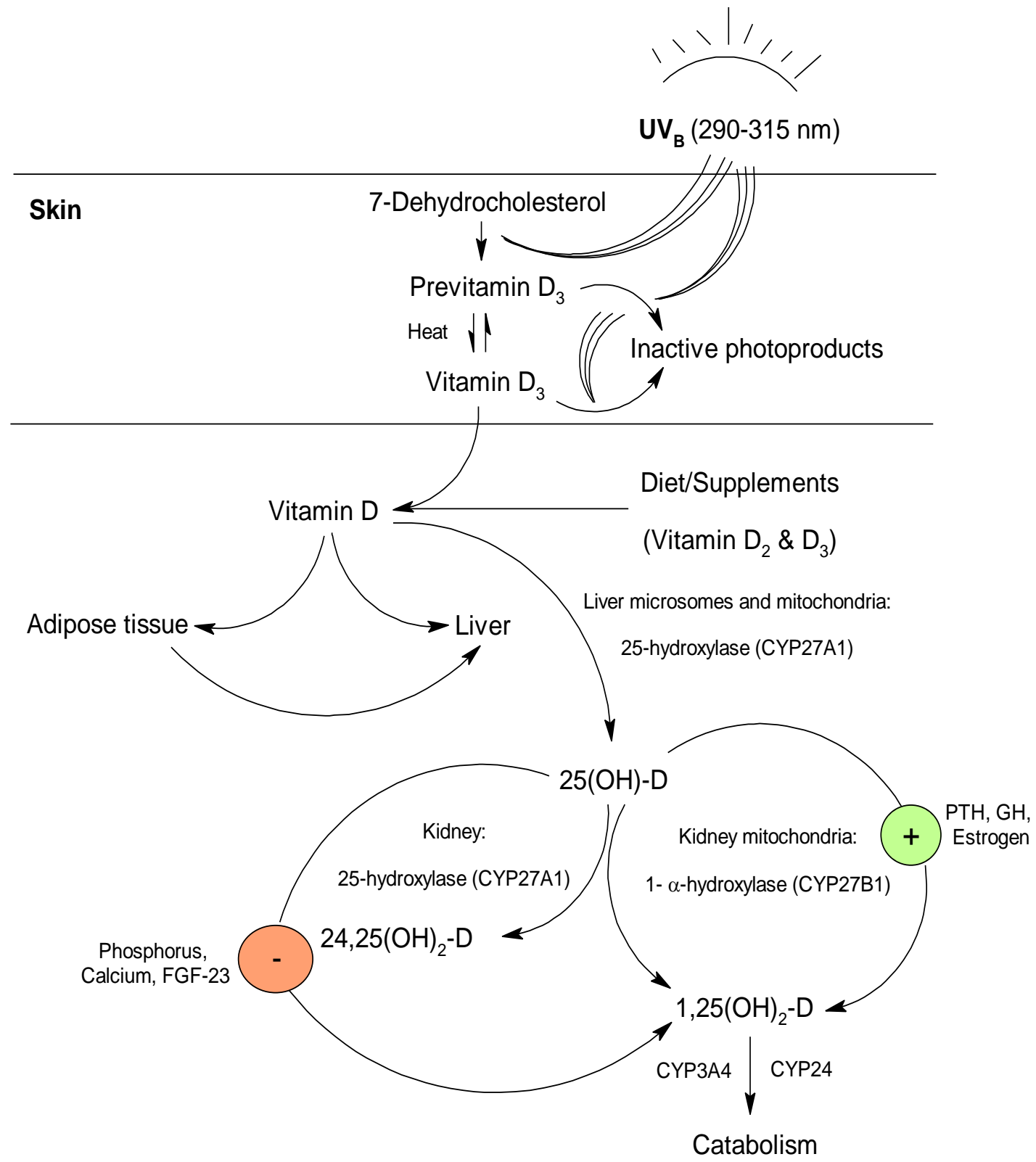

Figure 1.

Biosynthesis of vitamin $\mathrm{D}$ from sunlight

Legend: UV в: Ultraviolet ray B; PTH: Parathyroid hormone; GH: Growth hormone; FGF-23: Fibroblast growth factor 23 


\section{Tyrosine}

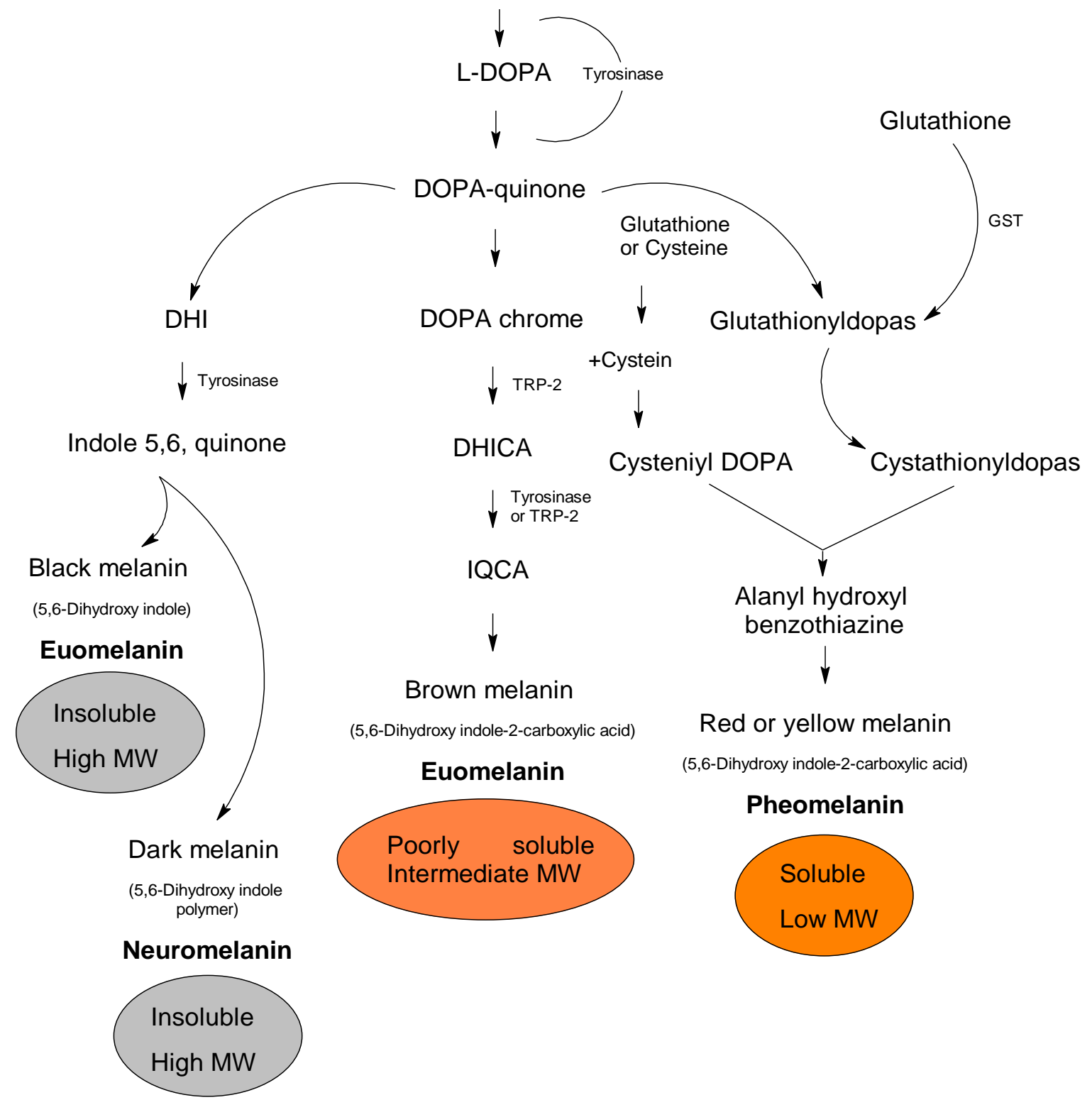

Figure 2.

Human melanin synthesis pathways

Legend: L-DOPA: Levodopa; DHI: 5,6-Dihydroxyindole; TRP-2: Tyrosinase-related protein 2; DHICA: 5,6-Dihydroxyindole-2-carboxylic acid; IQCA: Indole 5,6-quinone carboxylic acid; GST: Glutathione-S-transferase

It is due to the melanin absorbs UVB photons, resulting in competition with 7-dehydrocholesterol for the same UV radiation [20]. Black skin requires at least a 6-fold greater UVB dose to synthesize adequate circulating levels of Vit-D3 than the white skin [23]. On the other hand, 1,25(OH)2D3 is evident to regulate mineral homeostasis in our body [96]. Deficiency of certain minerals, such as copper [12], iron [53], selenium [66], sodium [100], magnesium [102], potassium [99], calcium [33] and zinc [19] is evident to increase susceptibility towards infectious agents, including viruses.
The skin colour depends on the complex interplay of UV radiation and hormones upon the genetical interference on the melanogenesis process of the individual [29, 49]. However, irrespective of skin melanin contents, the breastfed infants may have Vit-D deficiency as their Vit-D contents depend on the mother's Vit-D status [121]. On the other hand, the skin of the peoples (including older adults) cannot synthesize sufficient Vit-D, especially who spend more time indoors [70]. Most of the African and Americans having dark skin have the deficiency of Vit-D3 [6]. However, Vit-D deficiency or insufficiency is most common in the UK [95]. Figure 3 shows how melanin inhibits Vit-D synthesis in human skin. 


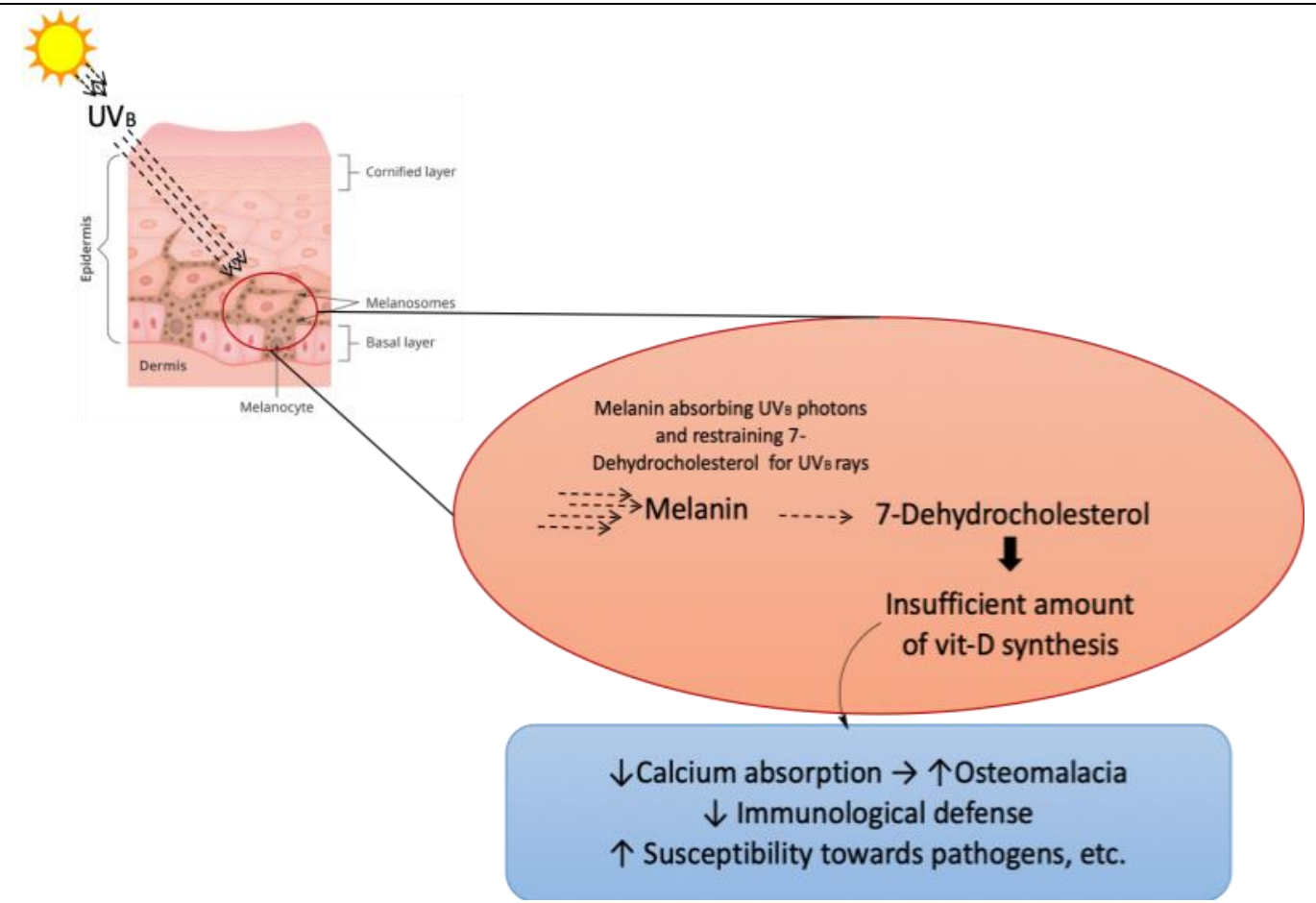

Figure 3.

Summarized scheme regarding the effects of melanin on Vit-D synthesis and its physiologic effects

\section{A tie-up between vitamin $D$, the risk of viral respiratory diseases and COVID-19}

It has been demonstrated that the SARS-CoV-2 uses the angiotensin-converting enzyme 2 (ACE2) receptor for attaching and entry into the human lung cells [123]. The ACE2 is evident for its lung-protective capacity [63].

Generally, the ACE2 catalyses the hydrolysis of the vasoconstrictor peptide angiotensin II into the vasodilator angiotensin [122]. One study suggests that angiotensin II stimulates the melanogenesis process through the protein kinase C (PKC) pathway [64]. In another study, Vit-D3 was seen to modulate the expression of ACE2 in lipopolysaccharide-induced lung injury Wistar rats [124]. Moreover, it also attenuated angiotensin II-induced nitrogen oxides (NOx) activation and reactive oxygen species (ROS) production [26]. The intracellular signal transduction pathways of cyclic adenosine monophosphate (cAMP), PKC and nitric oxide (NO) have been reported to regulate the melanogenesis process [62]. Therefore, upregulation of ACE2 will negatively affect the melanogenesis process in human.

Vit-D has immunomodulatory effects [52]. Vit-D deficiency or insufficiency implicates about 53\% of deaths from pneumonia of viral and bacterial origins in children worldwide [28]. Vit-D deficiency has been linked to increased risk of viral upper and lower respiratory tract infections (especially during winter time), wheezing and asthma-related hospitalizations in infants and children [2, 35].
Normal to high-serum levels of $25(\mathrm{OH}) \mathrm{D}$ may reduce in incidence and severity of viral infections [111]. On the other hand, the metabolites of Vit-D do not consistently influence the replication or clearance processes of viruses, including the rhinovirus, respiratory syncytial virus or influenza A virus in human respiratory epithelial cells. Furthermore, these metabolites have been found to modulate the expression and secretion of type 1 interferon, chemokines, including IL-8 or chemokine C-X-C motif chemokine ligand 8 (CXCL8) and IP-10 or CXCL10 and proinflammatory cytokines, such as TNF and IL-6 [41]. SARS-COV-2 infection is evident to upregulate many proinflammatory cytokines, including IL10, IP10 and TNF $\alpha$ in novel COVID-19 patients [46].

However, the effective supplementation of Vit-D needs to start before the onset of respiratory tract infection [2]. A recent study on the effect of Vit-D administration on acute respiratory tract infections showed that Vit-D administration significantly reduces the risk of contracting a respiratory disease [128]. The odds ratio was $0.65(0.5-0.85$ at $95 \%)$, a rate of 1 indicates that the exposure does not affect the result, while a rate of less than 1 indicates that the exposure the risk of outcome is reduced in this case of infection. Even though ingested Vit-D accumulates in adipose tissue, the study showed that it is more effective in preventing acute respiratory tract infections taken in daily doses than in weekly or monthly doses, and that blood levels should be or for this purpose at least $50 \mathrm{nmol} / \mathrm{L}$. Some studies have shown the beneficial effects of absorption with vitamin $\mathrm{D}$ in 
FARMACIA, 2020, Vol. 68, 6

association with probiotics [109]. Therefore, Zittermann et al. [128] recommend people at risk of Vit-D deficiency to take a daily dose of 1000 IU throughout the year, and the rest of the population to do so from early autumn to mid-spring. It can reduce the viral loads in our body possibly through the anti-viral immune induction, modulation of immunoregulatory defence processes, induction of autophagy and apoptosis, genetic or epigenetic regulation [43], stimulating the defensins and cathelicidins, thereby decreasing the viral RNA replication. It also increases the levels of anti-inflammatory cytokines, while reducing the proinflammatory cytokines those are evident to induce inflammation-related pneumonia. Vit-D-mediated reduced the death rate in COVID-19 patients having comorbidities (e.g., diabetes, hypertension) has been also reported by Kakodkar et al. [56].

It should be noted that the Vit-D deficiency is globally prevalent, particularly in the elders [120]. This high prevalence probably contributes to the first outbreak COVID-19 during winter and the high mortality rate in older adults [21]. Therefore, for people at risk of COVID-19, the goal should be to raise the concentrations of $25(\mathrm{OH}) \mathrm{D}$ above $40-60 \mathrm{ng} / \mathrm{mL}(100-150 \mathrm{nM} / \mathrm{L})$ by considering taking 10,000 IU/day of Vit-D3 for a few weeks to rapidly raise $25(\mathrm{OH}) \mathrm{D}$ concentrations, followed by $5000 \mathrm{IU} / \mathrm{d}$ [127]. Vit-D is known to mitigate the scope of acquired immunity and regenerate endothelial lining [58], that might be helpful to minimize the alveolar damage caused in acute respiratory distress syndrome (ARDS) in COVID-19 [27]. Vit-D inhibits viral replication [40] and causes dysregulation of the renin-angiotensin system and cytokine storm in the host through modulating the innate and adaptive immune system [7].

Knowing the overall facts, several clinical trials have undergone on the Vit-D aims to defend SARS-CoV-2 infection (Table 1).

Table I

Clinical trials on Vitamin D aiming to fight against SARS-CoV-2 related pathological conditions or comorbidities in COVID-19

\begin{tabular}{|c|c|c|c|c|}
\hline $\begin{array}{l}\text { Study Number/ } \\
\text { Sponsor }\end{array}$ & $\begin{array}{c}\text { Conditions/ } \\
\text { diseases }\end{array}$ & Dose of Vit-D & $\begin{array}{c}\text { Participants (age)/ } \\
\text { type of study }\end{array}$ & Reference \\
\hline $\begin{array}{c}\text { NCT04363840 } \\
\text { Louisiana State University Health Sciences } \\
\text { Center, } \\
\text { New Orleans }\end{array}$ & $\begin{array}{c}\text { COVID-19, } \\
\text { Vit-D } \\
\text { deficiency, } \\
\text { coagulopathy, } \\
\text { disseminated } \\
\text { intravascular } \\
\text { coagulation }\end{array}$ & $\begin{array}{l}50,000 \mathrm{IU}, \text { once weekly } \\
\text { for } 2 \text { weeks }\end{array}$ & $\begin{array}{c}1080 \text { (18 years - older) } \\
\text { (Phase } 2)\end{array}$ & [79] \\
\hline $\begin{array}{c}\text { NCT04407286 } \\
\text { Arizona State University with Southwest } \\
\text { College of Naturopathic Medicine }\end{array}$ & $\begin{array}{l}\text { COVID-19, } \\
\text { Vit-D } \\
\text { deficiency }\end{array}$ & $\begin{array}{c}10,000 \text { IU/day/BID } \\
(18-69 \text { years }) \\
15,000 \text { IU/day/TID } \\
\text { (age } 70+\text { ) for } 2 \text { weeks }\end{array}$ & $\begin{array}{c}100(18-70+\text { years }) \\
\quad(\text { Phase } 1)\end{array}$ & \\
\hline $\begin{array}{l}\text { NCT04385940 } \\
\text { University of Alberta }\end{array}$ & COVID-19 & $\begin{array}{c}1000 \mathrm{IU} \text { daily for } 2 \\
\text { weeks; } \\
50,000 \mathrm{IU} \text { for two } \\
\text { times during the } 1^{\text {st }} \\
\text { week and one dose } \\
\text { over } 2^{\text {nd }} \text { and } 3^{\text {rd }} \text { weeks }\end{array}$ & $\begin{array}{l}64 \text { (17 years) } \\
\text { (Phase } 3)\end{array}$ & [90] \\
\hline $\begin{array}{c}\text { NCT04386044 } \\
\text { Tameside General Hospital }\end{array}$ & $\begin{array}{l}\text { COVID-19 } \\
\text { Vit-D } \\
\text { deficiency }\end{array}$ & $\begin{array}{c}\text { Measurement of Vit-D } \\
\text { levels }\end{array}$ & $\begin{array}{c}1000 \text { (18 years to } \\
\text { older) } \\
\text { (Interventional) }\end{array}$ & \\
\hline $\begin{array}{l}\text { NCT04370808 } \\
\text { University of Lisbon }\end{array}$ & COVID-19 & $\begin{array}{l}\text { Investigation of Vit-D } \\
\text { polymorphism }\end{array}$ & $\begin{array}{l}500 \text { (18 years to older }) \\
\text { (Observational) }\end{array}$ & {$[83]$} \\
\hline $\begin{array}{c}\text { NCT04334005 } \\
\text { Universidad de Granada }\end{array}$ & COVID-19 & $\begin{array}{l}\text { 25,000 IU Vit-D } \\
\text { supplement for } 10 \\
\text { weeks }\end{array}$ & $\begin{array}{l}200 \text { (40 - } 70 \text { years }) \\
\quad(\text { Clinical trial })\end{array}$ & \\
\hline $\begin{array}{c}\text { NCT04435119 } \\
\text { University Hospital, Angers }\end{array}$ & COVID-19 & Vit-D3 supplementation & $\begin{array}{l}96 \text { (70 years to older) } \\
\text { (Observational) }\end{array}$ & [84] \\
\hline $\begin{array}{l}\text { NCT04407572 } \\
\text { Kanuni Sultan Suleyman Training, Research } \\
\text { Hospital with Ayşegül Bestel, İbrahim Polat, } \\
\text { Merve Aldıkaçtıŏlu Talmaç }\end{array}$ & $\begin{array}{l}\text { COVID-19 } \\
\text { Zn deficiency } \\
\text { Vit-D } \\
\text { deficiency }\end{array}$ & $\begin{array}{l}\text { Measurement of serum } \\
\text { Zn, Vit-D and Vit-B }{ }_{12} \\
\text { levels in pregnant } \\
\text { women }\end{array}$ & $\begin{array}{l}45 \text { (18 - } 45 \text { years }) \\
\text { (Observational study) }\end{array}$ & \\
\hline $\begin{array}{c}\text { NCT04394390 } \\
\text { Kanuni Sultan Suleyman Training and } \\
\text { Research Hospital with Ayşegül Bestel, }\end{array}$ & COVID-19 & & $\begin{array}{l}100 \text { (Child to older } \\
\text { adults) } \\
\text { (Observational) }\end{array}$ & [81] \\
\hline
\end{tabular}


FARMACIA, 2020, Vol. 68, 6

\begin{tabular}{|c|c|c|c|c|}
\hline $\begin{array}{l}\text { Study Number/ } \\
\text { Sponsor }\end{array}$ & $\begin{array}{c}\text { Conditions/ } \\
\text { diseases }\end{array}$ & Dose of Vit-D & $\begin{array}{l}\text { Participants (age)/ } \\
\text { type of study }\end{array}$ & Reference \\
\hline $\begin{array}{l}\text { NCT04335084 } \\
\text { ProgenaBiome }\end{array}$ & COVID-19 & $\begin{array}{l}\text { Vit-D with other } \\
\text { treatments }\end{array}$ & $\begin{array}{l}600 \text { (18 to older) } \\
\text { (Phase } 2)\end{array}$ & \\
\hline $\begin{array}{c}\text { NCT04400890 } \\
\text { Marvin McCreary, MD }\end{array}$ & COVID-19 & $100,000 \mathrm{IU}$ on day 1 & $\begin{array}{l}200 \text { (45 years - older) } \\
\text { (Phase 2) }\end{array}$ & [73] \\
\hline $\begin{array}{c}\text { NCT04344041 } \\
\text { University Hospital, Angers }\end{array}$ & COVID-19 & $\begin{array}{l}400,000 \text { or } 50,000 \mathrm{IU} \\
\text { in a single oral dose for } \\
2 \text { weeks }\end{array}$ & $\begin{array}{l}260 \text { (70 years - older }) \\
\text { (Phase } 3)\end{array}$ & \\
\hline $\begin{array}{c}\text { NCT04411446 } \\
\text { Vitamin D Study Group with Ag Nac }\end{array}$ & COVID-19 & $\begin{array}{l}\text { 100,000 IU orally one } \\
\text { dose, } 30 \text { days' time }\end{array}$ & $\begin{array}{c}1265 \text { ( } 70 \text { years - older) } \\
\text { (Phase } 4)\end{array}$ & [93] \\
\hline $\begin{array}{c}\text { Promoción de la Investigación, el Desarrollo } \\
\text { Tecnológico y la Innovación }\end{array}$ & & frame & & \\
\hline $\begin{array}{c}\text { NCT04403932 } \\
\text { Hospital San Carlos, Madrid }\end{array}$ & COVID-19 & $\begin{array}{l}\text { Risk assessment in vit- } \\
\text { D deficiency COVID- } \\
19 \text { patients }\end{array}$ & $\begin{array}{l}500 \text { (18 years - older }) \\
\text { (Observational })\end{array}$ & \\
\hline $\begin{array}{c}\text { NCT04351490 } \\
\text { University Hospital, Lille }\end{array}$ & COVID-19 & $\begin{array}{l}2000 \text { IU per day during } \\
2 \text { months' time frame }\end{array}$ & $\begin{array}{l}3140 \text { ( } 60 \text { years - older) } \\
\text { (Interventional) }\end{array}$ & [91] \\
\hline $\begin{array}{l}\text { NCT04395768 } \\
\text { National Institute of Integrative Medicine, } \\
\text { Australia with Catholic Health Initiatives }\end{array}$ & COVID-19 & $\begin{array}{l}5,000 \text { iu orally once per } \\
\text { day for } 2 \text { weeks with } \\
\text { other treatments }\end{array}$ & $\begin{array}{l}200 \text { (18 years - older } \\
\text { adults) (Phase } 2)\end{array}$ & \\
\hline $\begin{array}{l}\text { NCT04372017 } \\
\text { Sanford Health }\end{array}$ & COVID-19 & $\begin{array}{l}1600 \text { IU on day } 1 \text { and } \\
800 \text { IU on days } 2-5\end{array}$ & $\begin{array}{l}1 \text { (18 years }- \text { older }) \\
\text { (Phase } 3)\end{array}$ & {$[86]$} \\
\hline $\begin{array}{l}\text { NCT04334512 } \\
\text { ProgenaBiome }\end{array}$ & COVID-19 & $\begin{array}{l}\text { Vit-D with other } \\
\text { treatments }\end{array}$ & $\begin{array}{l}600 \text { (18 years }- \text { older }) \\
\text { (Phase } 2)\end{array}$ & \\
\hline $\begin{array}{c}\text { NCT04386850 } \\
\text { Tehran University of Medical Sciences }\end{array}$ & COVID-19 & $\begin{array}{l}25 \mu \mathrm{g} \text { once daily at } \\
\text { bedtime for } 2 \text { months }\end{array}$ & $\begin{array}{l}1500(18-75 \text { years }) \\
\quad(\text { Phase } 2 \& 3)\end{array}$ & {$[75]$} \\
\hline $\begin{array}{c}\text { NCT04360980 } \\
\text { Shahid Beheshti University of Medical } \\
\text { Sciences }\end{array}$ & COVID-19 & $\begin{array}{l}\text { Vit-D with other } \\
\text { treatments }\end{array}$ & $\begin{array}{l}80 \text { (18 years }- \text { older }) \\
\quad(\text { Phase } 2 \& 3)\end{array}$ & \\
\hline $\begin{array}{c}\text { NCT04366908 } \\
\text { Maimónides Biomedical Research Institute } \\
\text { of Córdoba }\end{array}$ & COVID-19 & $\begin{array}{l}\text { Calcifediol cap } 266 \mu \mathrm{g} \\
\text { at Days } 3,7,14,21,28 ; \\
\text { start with } 2 \text { caps }\end{array}$ & $\begin{array}{l}1008 \text { (18 - } 90 \text { years) } \\
\quad \text { (Phase 2) }\end{array}$ & {$[88]$} \\
\hline $\begin{array}{l}\text { NCT04326725 } \\
\text { Istinye University }\end{array}$ & COVID-19 & $\begin{array}{c}\text { Vit-D with other } \\
\text { treatments }\end{array}$ & $\begin{array}{l}80 \text { (20 - } 90 \text { years }) \\
\text { (Observational) }\end{array}$ & \\
\hline
\end{tabular}

It should be mentioned that the Flu or Flu-like transmissions are often coming out in cold and/or dry air [116] when a low UV index has been recorded [47]. Studies suggest that Vit-D levels increase in summer and decrease in winter [59]. It has been also depicted that the seasonal variation may depend on latitude since Vit-D production is more significant in equator [61] and sunny regions [37].

\section{Vitamin D status and the COVID-19 comorbidities}

Vit-D deficiency affects broad gene expression in humans, which is linked to many chronic diseases, including autoimmune and infectious diseases, cancers, type 2 diabetes and cardiovascular disease [45]. Vit$\mathrm{D}$ deficiency is one of the most consequences of secondary hyperparathyroidism, and it is evident to cause coagulopathy in human [34]. Moreover, the deficiency of this vitamin also causes liver diseases [11], cystic fibrosis [97], multiple sclerosis [52], prostate cancer [118], and so on.

Vit-D3 binds to the vitamin D receptor (VDR) which regulates transcription of more than 60 genes involved in anti-proliferative, pro-differentiating, anti-metastatic and pro-apoptotic effects on cells and the cell cycle
[3]. The VDR gene polymorphisms influence the risk of occurrence and prognosis of some cancers, such as breast and renal cancer [57]. The VDR also plays an essential role in calcium reabsorption in the kidney [54].

Vit-D is a fat-soluble vitamin, which requires dietary fats in the gut for its proper absorption. Therefore, peoples having reduced ability to absorb nutritional fats such those are suffering from liver disease, cystic fibrosis, and Crohn's disease might be required Vit-D supplements [20]. Moreover, peoples having obesity and who have undergone gastric bypass surgery may become Vit-D deficient [24]. A low serum 25(OH)D level has been also found to increase the risk of hypertension prevalence [5].

It has been also reported that the VDR gene polymorphisms are associated with diabetic nephropathy in human [107]. Hyperpigmentation is one of the common skin pigmentation disorders in diabetes mellitus patients [115]. Therefore, serum 25(OH)D levels may serve as a biomarker for these kinds of patients [32]. However, it does not indicate the actual amount of Vit-D stored in our body tissues. Yet, it has a circulating half-life of 15 days [55]. 
Vit-D has multiple functions in the body, the main one is the regulation of metabolism and calcium levels and for this reason, it was used in the form of cod liver oil to combat rickets in the first half of the twentieth century. Vit-D acts through its receptor, which is a transcription factor that regulates the expression of hundreds of genes, which is why it is involved in many processes. It is an immune system regulator that activates the innate response and regulates the adaptive response [22].

Low levels of Vit-D are associated with many of the comorbidities that predispose to a worse course of COVID-19 disease, such as hypertension, obesity, circulatory diseases and strokes. In addition, they are directly associated with an increased risk of death from several causes, including those caused by respiratory infections. Therefore, it is not surprising that researchers have found an association between mortality due to COVID-19 and Vit-D [10].

The results of recent meta-analyses revealed an association between serum $25(\mathrm{OH}) \mathrm{D}$ levels and the outcome of viral infection levels were lower among critical cases and higher in mild cases. Having some levels of a standard deviation above the average made the chances of having a mild form of the disease to be 8 times higher than a severe one and 20 times higher than critical [126].

Other recent studies showed a strong correlation between severe Vit-D deficiency and mortality rates after studying global data on the COVID-19 pandemic, a disease caused by the new SARS-CoV-2 coronavirus.

The researchers found that patients in countries with high mortality rates from COVID-19, such as Italy, Spain, and the United Kingdom, had low levels of Vit-D compared to patients in countries that were not as severely affected. of the pandemic [69].

It was found that there was a solid correlation between Vit-D levels and the "cytokine storm", a hyperinflammatory condition caused by an extremely active immune system, as well as a correlation between Vit-D deficiency and mortality believes that Vit-D plays a major role in terms of immunity [10]. Vit-D strengthens the innate immune system, but it prevents the immune system from becoming dangerously hyperactive. This means that when we have optimal levels of Vit-D in our body, it could protect patients against severe complications, including death, from COVID-19

A prospective study in patients with pneumonia reported that severe $25(\mathrm{OH})$ - D deficiency was associated with higher mortality rates compared to those with sufficient levels. The increase in mortality was not related to comorbid conditions, age or the severity of the acute disease [4].

In a very recent study led by Raharusun et al. [101], with 780 cases included in the study, it has been highlighted that $98.8 \%$ of patients with very low levels of Vit-D $(<20 \mathrm{ng} / \mathrm{mL})$ died, $87.8 \%$ of those with low levels (20.9 - $30 \mathrm{ng} / \mathrm{mL})$ and only $4.1 \%$ of those with normal levels (> $30 \mathrm{ng} / \mathrm{mL}$ ). Analysing the correlation of age, sex, and comorbidities in COVID19 patients, it was found that the probability of dying was 10 times higher in patients with low levels than in patients with normal Vit-D levels [101].

A new study conducted in 20 European countries shows that low levels of Vit-D are linked to the high number of COVID-19 cases, but also high mortality rates. The new data confirm the results of several previous observational studies, which reported an association between low levels of Vit-D and susceptibility to acute respiratory tract infections [50].

Scientists show that Vit-D modulates the response of white blood cells, preventing them from releasing too many inflammatory cytokines. The SARS-CoV-2 virus causes an excess of proinflammatory cytokines [50].

Research shows that the population in Italy and Spain has average levels of Vit-D, lower than the people in most northern European countries. In fact, in Spain and Italy, there were high mortality rates due to COVID-19. One explanation for this would be that people in southern Europe, especially the elderly, avoid the intense sun, while skin pigmentation also reduces the natural synthesis of Vit-D [44].

In contrast, the highest average levels of Vit-D are found in northern Europe, due to the consumption of cod liver oil and Vit-D supplements. Currently, the Scandinavian countries are among the countries with the lowest number of COVID-19 cases and with low mortality rates per capita in Europe.

A significant relationship was thus found between the average levels of Vit-D and the number of cases of COVID-19, and, in particular, between the average level of Vit-D and the mortality rate of COVID-19 [10]. Vit-D has been shown to protect against acute respiratory infections, and older adults, the most deficient group in Vit-D, are most severely affected by COVID-19.

\section{Overall Conclusion and future perspectives}

Many studies on Vit-D and the link with COVID-19 are observational studies; and by definition, these studies cannot prove the causal relationship, indicating only simple correlations.

Thus, none of the intervention studies conducted to date, in which the effect of Vit-D administration on several diseases was specifically examined, could confirm the previous combination and laboratory studies and the alleged positive impact of Vit-D.

On the other hand, if a coronavirus infection is suspected, the patient's Vit-D level should be checked by clinicians, and an immediate Vit-D deficiency should be remedied immediately. Vit-D deficiency may play a role in reducing the severe symptoms of COVID-19 mourning, but Vit-D should not be given 
to all patients. This correlation should be studied in more detail and confirmed by other clinical trials. Therefore, Vit-D can be considered as a new synergic treatment for COVID-19.

A high melanin deposition results in dark colour skin, which is helpful to protect us from many diseases (e.g., skin infections and cancer), however, it inhibits the synthesis of Vit-D in the skin. The angiotensin II stimulates the process of melanogenesis, which could be downregulated by overexpression of ACE2. Although the ACE2 plays a vital role in the entrance of SARSCoV-2 in our body, ACE2 is evident for its lungprotective capacity. Therefore, the peoples having low levels of ACE2 will not get much defensive power over the high ACE2 content peoples. Further, a reduction of ACE2 may increase the levels of angiotensin II, thereby, upregulates the contents of melanogenesis process, which is inversely related to the Vit-D synthesis in our body. Therefore, the peoples having a dark colour skin or highly pigmented skin, especially who are deficient in Vit-D might be in the risk zone in COVID-19. Adequate exposure of sunlight along with the taking of food supplements rich in Vit-D might be an option to fight against the pandemic SARS-CoV-2 outbreak of these kinds of peoples.

\section{Abbreviation List}

ACE2: angiotensin-converting enzyme 2; ARDS: acute respiratory distress syndrome; cAMP: cyclic adenosine monophosphate; CXCL: chemokine $\mathrm{C}-\mathrm{X}-\mathrm{C}$ motif chemokine ligand; G-CSF: granulocyte colony-stimulating factor; EN-RAGE: an extracellular newly identified receptor for advanced glycation end-products binding protein; IL: interleukin; IP-10: interferon-gammainducible protein-10; MCP-1: monocyte chemotactic protein-1; MERS: middle east respiratory syndrome; NO: nitric oxide; NOx: nitrogen oxides; PKC: protein kinase C; ROS: reactive oxygen species; SARS: severe acute respiratory syndrome; SARS-CoV-2: severe acute respiratory syndrome coronavirus 2 ; TNF- $\alpha$ : tumour necrosis factor-alpha; TNFSF14: tumour necrosis factor superfamily member 14; UV: ultraviolet; VDR: vitamin D receptor; Vit-D: vitamin D.

\section{Conflict of interest}

The authors declare no conflict of interest.

\section{References}

1. Abdel-Malek ZA, Swope VB, Epidermal melanocytes: regulation of their survival, proliferation, and function in human skin. Melanoma Development: Springer; 2011: 7-33.

2. Aglipay M, Birken CS, Parkin PC, Loeb MB, Thorpe K, Chen Y, Laupacis A, Mamdani M, Macarthur C, Hoch JS. Effect of high-dose vs standard-dose wintertime vitamin D supplementation on viral upper respiratory tract infections in young healthy children. JAMA, 2017; 318(3): 245-254.

3. Ali MM, Vaidya V, Vitamin D and cancer. J Cancer Res Ther., 2007; 3(4): 225-230.

4. Ali N, Role of vitamin D in preventing of COVID-19 infection, progression and severity. J Infect Public Health, 2020; 13(10): 1373-1380.

5. Almirall J, Vaqueiro M, Bare ML, Anton E, Association of low serum 25-hydroxyvitamin D levels and high arterial blood pressure in the elderly. Nephrol Dial Transplant., 2010; 25(2): 503-509.

6. Alzaman NS, Dawson-Hughes B, Nelson J, D'Alessio D, Pittas AG, Vitamin D status of black and white Americans and changes in vitamin D metabolites after varied doses of vitamin D supplementation. Am J Clin Nutr., 2016; 104(1): 205-214.

7. Aranow C, Vitamin D and the immune system. J Investig Med., 2011; 59(6): 881-886.

8. Arsene AL, Dumitrescu IB, Dragoi CM, Udeanu DI, Lupuliasa D, Jinga V, Draganescu D, Dinu-Pirvu CE, Burcea Dragomiroiu GTA, Blejan IE, Moisi RE, Nicolae AC, Moldovan H, Popa DE, Velescu BS, Ruta S, A new era for the therapeutic management of the ongoing COVID-19 pandemic. Farmacia, 2020; 68(2): 185-196.

9. Arunachalam PS, Wimmers F, Mok CKP, Perera RAPM, Scott M, Hagan T, Sigal N, Feng Y, Bristow L, Tak-Yin Tsang O, Wagh D, Coller J, Pellegrini KL, Kazmin D, Alaaeddine G, Leung WS, Chan JMC, Chik TSH, Choi CYC, Huerta C, Paine McCullough M, Lv H, Anderson E, Edupuganti S, Upadhyay AA, Bosinger SE, Maecker HT, Khatri P, Rouphael N, Peiris M, Pulendran B, Systems biological assessment of immunity to mild versus severe COVID-19 infection in humans. Science, 2020; 369(6508): 1210-1220.

10. Biesalski HK, Vitamin D deficiency and co-morbidities in COVID-19 patients - A fatal relationship?. NFS Journal, 2020; 20: 10-21.

11. Bjelakovic G, Nikolova D, Bjelakovic M, Gluud C, Vitamin D supplementation for chronic liver diseases in adults. Cochrane Database Syst Rev., 2017; 11(11): CD011564.

12. Borkow G, Sidwell RW, Smee DF, Barnard DL, Morrey JD, Lara-Villegas HH, Shemer-Avni Y, Gabbay $\mathrm{J}$, Neutralizing viruses in suspensions by copper oxidebased filters. Antimicrob Agents Chemother., 2007; 51(7): 2605-2607.

13. Brenner M, Hearing VJ, The protective role of melanin against UV damage in human skin. Photochem Photobiol., 2008; 84(3): 539-549.

14. Calina D, Docea AO, Golokhvast KS, Sifakis S, Tsatsakis A, Makrigiannakis A, Management of Endocrinopathies in Pregnancy: A Review of Current Evidence. Int J Environ Res Public Health., 2019; 16(5): 1-25.

15. Calina D, Docea AO, Petrakis D, Egorov AM, Ishmukhametov AA, Gabibov AG, Shtilman MI, Kostoff R, Carvalho F, Vinceti M, Spandidos DA, Tsatsakis A, Towards effective COVID-19 vaccines: Updates, perspectives and challenges (Review). Int J Mol Med., 2020; 46(1): 3-16.

16. Calina D, Hartung T, Docea AO, Spandidos DA, Egorov AM, Shtilman MI, Carvalho F, Tsatsakis A, 
COVID-19 vaccines: ethical framework concerning human challenge studies. Daru, 2020: 1-6.

17. Calina D, Sarkar C, Arsene AL, Salehi B, Docea AO, Mondal M, Islam MT, Zali A, Sharifi-Rad J. Recent advances, approaches and challenges in targeting pathways for potential COVID-19 vaccines development. Immunol Res., 2020; 68(6): 315-324.

18. Catrinoiu D, Ceriello A, Rizzo M, Serafinceanu C, Montano N, Stoian AP, Udeanu DI, Jinga V, Iorgulescu G, Dumitrescu IB, Diabetes and reninangiotensin-aldosterone system: implications for COVID19 patients with diabetes treatment management. Farmacia, 2020; 68(3): 377-383.

19. Chai W, Zakrzewski SS, Gunzel D, Pieper R, Wang Z, Twardziok S, Janczyk P, Osterrieder N, Burwinkel $\mathrm{M}$, High-dose dietary zinc oxide mitigates infection with transmissible gastroenteritis virus in piglets. $B M C$ Vet Res., 2014; 10: 1-10.

20. Chen TC, Chimeh F, Lu Z, Mathieu J, Person KS, Zhang A, Kohn N, Martinello S, Berkowitz R, Holick MF, Factors that influence the cutaneous synthesis and dietary sources of vitamin D. Arch Biochem Biophys., 2007; 460(2): 213-217.

21. Choi R, Kim S, Yoo H, Cho YY, Kim SW, Chung JH, Oh SY, Lee SY, High prevalence of vitamin D deficiency in pregnant Korean women: the first trimester and the winter season as risk factors for vitamin D deficiency. Nutrients, 2015;7(5): 3427-3448.

22. Chun RF, Liu PT, Modlin RL, Adams JS, Hewison $\mathrm{M}$, Impact of vitamin D on immune function: lessons learned from genome-wide analysis. Front Physiol., 2014; 5(151): 1-15.

23. Clemens TL, Adams JS, Henderson SL, Holick MF, Increased skin pigment reduces the capacity of skin to synthesise vitamin D3. Lancet, 1982; 1(8263): 74-76.

24. Compher CW, Badellino KO, Boullata JI, Vitamin $\mathrm{D}$ and the bariatric surgical patient: a review. Obes Surg., 2008;18(2): 220-224.

25. Costela-Ruiz VJ, Illescas-Montes R, Puerta-Puerta JM, Ruiz C, Melguizo-Rodriguez L, SARS-CoV-2 infection: The role of cytokines in COVID-19 disease. Cytokine Growth Factor Rev., 2020; 54: 62-75.

26. Cui C, Xu P, Li G, Qiao Y, Han W, Geng C, Liao D, Yang M, Chen D, Jiang P, Vitamin D receptor activation regulates microglia polarization and oxidative stress in spontaneously hypertensive rats and angiotensin IIexposed microglial cells: Role of renin-angiotensin system. Redox Biol., 2019; 26: 1-11.

27. Dancer RC, Parekh D, Lax S, D'Souza V, Zheng S, Bassford CR, Park D, Bartis DG, Mahida R, Turner AM, Sapey E, Wei W, Naidu B, Stewart PM, Fraser WD, Christopher KB, Cooper MS, Gao F, Sansom DM, Martineau AR, Perkins GD, Thickett DR, Vitamin $\mathrm{D}$ deficiency contributes directly to the acute respiratory distress syndrome (ARDS). Thorax, 2015; 70(7): 617-624.

28. Das RR, Singh M, Naik SS, Vitamin D as an adjunct to antibiotics for the treatment of acute childhood pneumonia. Cochrane Database Syst Rev., 2018; 7(7): Cd011597.

29. Del Bino S, Duval C, Bernerd F, Clinical and Biological Characterization of Skin Pigmentation Diversity and Its Consequences on UV Impact. Int $\mathrm{J} \mathrm{Mol} \mathrm{Sci.,}$ 2018; 19(9): 1-44.
30. Dhama K, Patel SK, Pathak M, Yatoo MI, Tiwari R, Malik YS, Singh R, Sah R, Rabaan AA, BonillaAldana DK, Rodriguez-Morales AJ, An update on SARS-CoV-2/COVID-19 with particular reference to its clinical pathology, pathogenesis, immunopathology and mitigation strategies. Travel Med Infect Dis., 2020: 101755 .

31. Docea AO, Tsatsakis A, Albulescu D, Cristea O, Zlatian O, Vinceti M, Moschos SA, Tsoukalas D, Goumenou M, Drakoulis N, Dumanov JM, Tutelyan VA, Onischenko GG, Aschner M, Spandidos DA, Calina D, A new threat from an old enemy: Reemergence of coronavirus (Review). Int J Mol Med., 2020; 45(6): 1631-1643.

32. DRI, Institute of Medicine, Food and Nutrition Board, Dietary Reference Intakes: energy, carbohydrate, fiber, fat, fatty acids, cholesterol, protein and amino acids. The National Academy Washington; 2005.

33. Dube M, Etienne L, Fels M, Kielian M, CalciumDependent Rubella Virus Fusion Occurs in Early Endosomes. J Virol., 2016;90(14):6303-6313.

34. Elbers LPB, Wijnberge M, Meijers JCM, Poland DCW, Brandjes DPM, Fliers E, Gerdes VEA, Coagulation and fibrinolysis in hyperparathyroidism secondary to vitamin D deficiency. Endocr Connect., 2018; 7(2): 325-333.

35. Esposito S, Lelii M, Vitamin D and respiratory tract infections in childhood. BMC Infect Dis., 2015; 15: 1-10.

36. Farsalinos K, Niaura R, Le Houezec J, Barbouni A, Tsatsakis A, Kouretas D, Vantarakis A, Poulas K, Editorial: Nicotine and SARS-CoV-2: COVID-19 may be a disease of the nicotinic cholinergic system. Toxicology reports, 2020; 7: 658-663.

37. Fields J, Trivedi NJ, Horton E, Mechanick JI, Vitamin $\mathrm{D}$ in the Persian Gulf: integrative physiology and socioeconomic factors. Curr Osteoporos Rep., 2011; 9(4): 243-250.

38. Goumenou M, Sarigiannis D, Tsatsakis A, Anesti O, Docea AO, Petrakis D, Tsoukalas D, Kostoff R, Rakitskii V, Spandidos DA, Aschner M, Calina D, COVID-19 in Northern Italy: An integrative overview of factors possibly influencing the sharp increase of the outbreak (Review). Mol Med Rep., 2020; 22(1): 20-32.

39. Grant WB, Al Anouti F, Moukayed M, Targeted 25-hydroxyvitamin D concentration measurements and vitamin D3 supplementation can have important patient and public health benefits. Eur J Clin Nutrit., 2020; 74(3): 366-376.

40. Grant WB, Lahore H, McDonnell SL, Baggerly CA, French CB, Aliano JL, Bhattoa HP, Evidence that Vitamin D Supplementation Could Reduce Risk of Influenza and COVID-19 Infections and Deaths. Nutrients, 2020; 12(4): 1-19.

41. Greiller CL, Martineau AR, Modulation of the immune response to respiratory viruses by vitamin D. Nutrients, 2015; 7(6): 4240-4270.

42. Grigorie D, Caragheorgheopol A, Coleș D, Șucaliuc A, Comparison of long term oral supplementation with two dosages of cholecalciferol on serum 25 hydroxyvitamin D in patients with postmenopausal osteoporosis. Farmacia, 2019; 67(5): 830-835. 
43. Gruber-Bzura BM, Vitamin D and InfluenzaPrevention or Therapy? Int J Mol Sci., 2018; 19(8): $1-25$.

44. Hedlund R, Diamond TK, Uversky VN, The latitude hypothesis, vitamin D, and SARS-Co-V2. J Biomol Struct Dyn., 2020: 1-3.

45. Hossein-Nezhad A, Spira A, Holick MF, Influence of vitamin D status and vitamin D 3 supplementation on genome wide expression of white blood cells: a randomized double-blind clinical trial. PloS one, 2013; 8(3): 1-13.

46. Huang C, Wang Y, Li X, Ren L, Zhao J, Hu Y, Zhang L, Fan G, Xu J, Gu X, Clinical features of patients infected with 2019 novel coronavirus in Wuhan, China. Lancet, 2020; 395(10223): 497-506.

47. Ianevski A, Zusinaite E, Shtaida N, Kallio-Kokko H, Valkonen M, Kantele A, Telling K, Lutsar I, Letjuka $\mathrm{P}$, Metelitsa N, Low temperature and low UV indexes correlated with peaks of influenza virus activity in Northern Europe during 2010-2018. Viruses, 2019; 11(3): 1-10.

48. Ianosi S, Ianosi G, Neagoe D, Ionescu O, Zlatian O, Docea AO, Badiu C, Sifaki M, Tsoukalas D, Tsatsakis AM, Spandidos DA, Calina D, Age-dependent endocrine disorders involved in the pathogenesis of refractory acne in women. Mol Med Rep., 2016; 14(6): 5501-5506.

49. Ianoși SL, Batani A, Ilie MA, Tampa M, Georgescu SR, Zurac S, Boda D, Ianosi NG, Neagoe D, Calina D, Tutunaru C, Constantin C, Non-invasive imaging techniques for the in vivo diagnosis of Bowen's disease: Three case reports. Oncol Lett., 2019; 17(5): 4094-4101.

50. Ilie PC, Stefanescu S, Smith L, The role of vitamin D in the prevention of coronavirus disease 2019 infection and mortality. Aging Clin Exp Res., 2020; 32(7): 1195-1198.

51. Islam M, Beneficial aspects of ultraviolet rays in protective and sound health. EC Pharmacol Toxicol., 2018; 6(2): 57-65.

52. Jagannath VA, Filippini G, Di Pietrantonj C, Asokan GV, Robak EW, Whamond L, Robinson SA, Vitamin $\mathrm{D}$ for the management of multiple sclerosis. Cochrane Database Syst Rev., 2018; 9(9): CD008422.

53. Jayaweera J, Reyes M, Joseph A, Childhood iron deficiency anemia leads to recurrent respiratory tract infections and gastroenteritis. Sci Rep., 2019;9(1): 1-8.

54. Johnson JA, Grande JP, Roche PC, Sweeney WE, Jr., Avner ED, Kumar R, 1 alpha, 25-dihydroxyvitamin D3 receptor ontogenesis in fetal renal development. Am J Physiol., 1995; 269(3 Pt 2): F419-F428.

55. Jones G, Pharmacokinetics of vitamin D toxicity. Am J Clin Nutr., 2008; 88(2): 582s-586s.

56. Kakodkar P, Kaka N, Baig MN, A Comprehensive Literature Review on the Clinical Presentation, and Management of the Pandemic Coronavirus Disease 2019 (COVID-19). Cureus, 2020; 12(4): 1-18.

57. Khan MI, Bielecka ZF, Najm MZ, Bartnik E, Czarnecki JS, Czarnecka AM, Szczylik C, Vitamin $\mathrm{D}$ receptor gene polymorphisms in breast and renal cancer: current state and future approaches (review). Int J Oncol., 2014; 44(2): 349-363.

58. Kim DH, Meza CA, Clarke H, Kim JS, Hickner RC, Vitamin D and Endothelial Function. Nutrients, 2020; 12(2): 1-17.
59. Klingberg E, Oleröd G, Konar J, Petzold M, Hammarsten O, Seasonal variations in serum 25hydroxy vitamin D levels in a Swedish cohort. Endocrine, 2015; 49(3): 800-808.

60. Kostoff RN, Kanduc D, Porter AL, Shoenfeld Y, Calina D, Briggs MB, Spandidos DA, Tsatsakis A, Vaccine- and natural infection-induced mechanisms that could modulate vaccine safety. Tox Rep., 2020; 7: $1448-1458$.

61. Ladizesky M, Lu Z, Oliveri B, San Roman N, Diaz S, Holick MF, Mautalen C, Solar ultraviolet B radiation and photoproduction of vitamin D3 in central and southern areas of Argentina. J Bone Miner Res., 1995; 10(4): 545-549.

62. Lee AY, Noh M, The regulation of epidermal melanogenesis via cAMP and/or PKC signaling pathways: insights for the development of hypopigmenting agents. Arch Pharm Res., 2013; 36(7): 792-801.

63. Li Y, Zeng Z, Li Y, Huang W, Zhou M, Zhang X, Jiang W, Angiotensin-converting enzyme inhibition attenuates lipopolysaccharide-induced lung injury by regulating the balance between angiotensin-converting enzyme and angiotensin-converting enzyme 2 and inhibiting mitogen-activated protein kinase activation. Shock, 2015; 43(4): 395-404.

64. Liu LH, Fan X, Xia ZK, An XX, Yang RY, Angiotensin II stimulates melanogenesis via the protein kinase C pathway. Exp Ther Med., 2010; 10(4): 15281532.

65. Lucas RM, Ponsonby AL, Considering the potential benefits as well as adverse effects of sun exposure: can all the potential benefits be provided by oral vitamin D supplementation?. Prog Biophys Mol Biol., 2006; 92(1): 140-149.

66. Ma X, Bi S, Wang Y, Chi X, Hu S, Combined adjuvant effect of ginseng stem-leaf saponins and selenium on immune responses to a live bivalent vaccine of Newcastle disease virus and infectious bronchitis virus in chickens. Poult Sci., 2019; 98(9): 3548-3556.

67. Masuda Y, Yamashita T, Hirao T, Takahashi M. An innovative method to measure skin pigmentation. Skin Res Technol., 2009; 15(2): 224-229.

68. Misra M, Pacaud D, Petryk A, Collett-Solberg PF, Kappy M, Vitamin D deficiency in children and its management: review of current knowledge and recommendations. Pediatrics, 2008; 122(2): 398-417.

69. Mitchell F, Vitamin-D and COVID-19: do deficient risk a poorer outcome?. The Lancet Diabetes \& Endocrinology, 2020; 8(7): 570.

70. Nair R, Maseeh A, Vitamin D: The "sunshine" vitamin. J Pharmacol Pharmacother., 2012; 3(2): 118-126.

71. Nasi A, McArdle S, Gaudernack G, Westman G, Melief C, Rockberg J, Arens R, Kouretas D, Sjölin J, Reactive oxygen species as an initiator of toxic innate immune responses in retort to SARS-CoV-2 in an ageing population, consider $\mathrm{N}$-acetylcysteine as early therapeutic intervention. Tox Rep, 2020; 7: 768-771.

72. NCT04326725, Proflaxis Using Hydroxychloroquine Plus Vitamins-Zinc During COVID-19 Pandemia. ClinicalTrials.gov, 2020.

73. NCT04334005, Vitamin D on Prevention and Treatment of COVID-19 (COVITD-19). ClinicalTrials.gov, 2020. 
74. NCT04334512, A Study of Quintuple Therapy to Treat COVID-19 Infection (HAZDpaC). ClinicalTrials. gov, 2020.

75. NCT04335084, A Study of Hydroxychloroquine, Vitamin C, Vitamin D, and Zinc for the Prevention of COVID-19 Infection (HELPCOVID-19). Clinical Trials.gov, 2020.

76. NCT04344041, COvid-19 and Vitamin D Supplementation: a Multicenter Randomized Controlled Trial of High Dose Versus Standard Dose Vitamin D3 in High-risk COVID-19 Patients (CoVitTrial). ClinicalTrials.gov, 2020.

77. NCT04351490, Impact of Zinc and Vitamin D3 Supplementation on the Survival of Aged Patients Infected With COVID-19 (ZnD3-CoVici). Clinical Trials.gov, 2020.

78. NCT04360980, The Effects of Standard Protocol With or Without Colchicine in Covid-19 Infection. ClinicalTrials.gov, 2020.

79. NCT04363840, The LEAD COVID-19 Trial: Lowrisk, Early Aspirin and Vitamin D to Reduce COVID19 Hospitalizations. ClinicalTrials.gov, 2020.

80. NCT04366908, Prevention and Treatment With Calcifediol of COVID-19 Induced Acute Respiratory Syndrome (COVIDIOL). ClinicalTrials.gov, 2020.

81. NCT04370808, VITACOV: Vitamin D Polymorphisms and Severity of COVID-19 Infection (VITACOV). ClinicalTrials.gov, 2020.

82. NCT04372017, Hydroxychloroquine as Post-Exposure Prophylaxis Against COVID-19 Infection. Clinical Trials.gov, 2020.

83. NCT04385940, Vitamin D and COVID-19 Management. ClinicalTrials.gov. 2020.

84. NCT04386044, Investigating the Role of Vitamin D in the Morbidity of COVID-19 Patients. Clinical Trials.gov, 2020

85. NCT04386850, Oral 25-hydroxyvitamin D3 and COVID-19. ClinicalTrials.gov, 2020.

86. NCT04394390, Do Vitamin D Levels Really Correlated With Disease Severity in COVID-19 Patients? (COVIDVIT). ClinicalTrials.gov, 2020.

87. NCT04395768, International ALLIANCE Study of Therapies to Prevent Progression of COVID-19. ClinicalTrials.gov, 2020.

88. NCT04400890. Randomized Proof-of-Concept Trial to Evaluate the Safety and Explore the Effectiveness of a Dietary Supplement for COVID-19. ClinicalTrials.gov. 2020.

89. NCT04403932, Covid-19 and Vitamin D in Nursinghome (COVIT-EHPAD). ClinicalTrials.gov, 2020.

90. NCT04407286, Vitamin D Testing and Treatment for COVID 19. ClinicalTrials.gov, 2020.

91. NCT04407572, Evaluation of the Relationship Between Zinc Vitamin D and b12 Levels in the Covid-19 Positive Pregnant Women. ClinicalTrials.gov, 2020.

92. NCT04411446, Cholecalciferol to Improve the Outcomes of COVID-19 Patients (CARED). Clinical Trials.gov, 2020.

93. NCT04435119, Covid-19 and Vitamin D in Nursinghome (COVIT-EHPAD). ClinicalTrials.gov, 2020.

94. Park A, Iwasaki A, Type I and Type III Interferons \&\#x2013; Induction, Signaling, Evasion, and Application to Combat COVID-19. Cell Host \& Microbe, 2020; 27(6): 870-878.
95. Pearce SH, Cheetham TD. Diagnosis and management of vitamin D deficiency. BMJ, 2010; 340: b5664, doi: $10.1136 / \mathrm{bmj} . b 5664$.

96. Pike JW, Shevde NK, Vitamin D: Nuclear Receptor for 1,25(OH)2D3. In: Henry HL, Norman AW, editors. Encyclopedia of Hormones. New York: Academic Press; 2003. p. 650-6.

97. Stan IV, Bălănescu A, Codreanu IF, Belivaca AA, Ritivoiu ME, Drăgoi MM, Marinescu SA, Ali C, Comănici VD, 25(OH) vitamin D deficiency in cystic fibrosis children - a prospective study on prevalence and treatment outcome. Farmacia, 2019; 67(3): 423-429.

98. Pollán M, Pérez-Gómez B, Pastor-Barriuso R, Oteo J, Hernán MA, Pérez-Olmeda M, Sanmartín JL, Fernández-García A, Cruz I, Fernández de Larrea N, Molina M, Rodríguez-Cabrera F, Martín M, MerinoAmador P, León Paniagua J, Muñoz-Montalvo JF, Blanco F, Yotti R; ENE-COVID Study Group, Prevalence of SARS-CoV-2 in Spain (ENE-COVID): a nationwide, population-based seroepidemiological study. The Lancet, 2020; 396(10250): 535-544.

99. Punch EK, Hover S, Blest HTW, Fuller J, Hewson R, Fontana J, Mankouri J, Barr JN, Potassium is a trigger for conformational change in the fusion spike of an enveloped RNA virus. J Biol Chem., 2018; 293(26): 9937-9944.

100. Quan FS, Rubino I, Lee SH, Koch B, Choi HJ, Universal and reusable virus deactivation system for respiratory protection. Sci Rep., 2017; 7(1): 1-10.

101. Raharusun P, Priambada S, Budiarti C, Agung E, Budi C, Patterns of COVID-19 Mortality and Vitamin D: An Indonesian Study. SSRN Electronic Journal, 2020.

102. Ravell J, Otim I, Nabalende H, Legason ID, Reynolds SJ, Ogwang MD, Ndugwa CM, Marshall V, Whitby D, Goedert JJ, Engels EA, Bhatia K, Lenardo MJ, Mbulaiteye SM, Plasma magnesium is inversely associated with Epstein-Barr virus load in peripheral blood and Burkitt lymphoma in Uganda. Cancer Epidemiol., 2018; 52: 70-74.

103. Rees JL, Genetics of hair and skin color. Annu Rev Genet., 2003; 37(1): 67-90.

104. Salehi B, Rescigno A, Dettori T, Calina D, Docea AO, Singh L, Cebeci F, Ozcelik B, Bhia M, Dowlati Beirami A, Sharifi-Rad J, Sharopov F, Cho WC, Martins N, Avocado-Soybean Unsaponifiables: A Panoply of Potentialities to Be Exploited. Biomolecules, 2020; 10(1): 1-20.

105. Sanders JM, Monogue ML, Jodlowski TZ, Cutrell JB, Pharmacologic Treatments for Coronavirus Disease 2019 (COVID-19): A Review. JAMA, 2020; 323(18): 1824-1836.

106. Sarkar C, Mondal M, Torequl Islam M, Martorell M, Docea AO, Maroyi A, Sharifi-Rad J, Calina D, Potential Therapeutic Options for COVID-19: Current Status, Challenges, and Future Perspectives. Front Pharmacol., 2020; 11: 1-30.

107. Schiller A, Gadalean F, Schiller O, Timar R, Bob F, Munteanu M, Stoian D, Mihaescu A, Timar B, Vitamin $\mathrm{D}$ deficiency-prognostic marker or mortality risk factor in end stage renal disease patients with diabetes mellitus treated with hemodialysis-a prospective multicenter study. PLoS One, 2015;10(5): 1-13. 
108. Sharifi-Rad J, Rodrigues CF, Sharopov F, Docea AO, Can Karaca A, Sharifi-Rad M, Kahveci Karincaoglu D, Gulseren G, Senol E, Demircan E, Taheri Y, Suleria HAR, Ozcelik B, Nur Kasapoglu K, Gultekin-Ozguven M, Daskaya-Dikmen C, Cho WC, Martins N, Calina D, Diet, Lifestyle and Cardiovascular Diseases: Linking Pathophysiology to Cardioprotective Effects of Natural Bioactive Compounds. Int $J$ Environ Res Public Health., 2020; 17(7): 1-31.

109. Sharifi-Rad J, Rodrigues CF, Stojanović-Radić Z, Dimitrijević M, Aleksić A, Neffe-Skocińska K, Zielińska D, Kołożyn-Krajewska D, Salehi B, Milton Prabu S, Schutz F, Docea AO, Martins N, Calina D, Probiotics: Versatile Bioactive Components in Promoting Human Health. Medicina, 2020; 56(9): 1-30.

110. Sharifi-Rad M, Anil Kumar NV, Zucca P, Varoni EM, Dini L, Panzarini E, Rajkovic J, Tsouh Fokou PV, Azzini E, Peluso I, Prakash Mishra A, Nigam M, El Rayess Y, Beyrouthy ME, Polito L, Iriti M, Martins N, Martorell M, Docea AO, Setzer WN, Calina D, Cho WC, Sharifi-Rad J, Lifestyle, Oxidative Stress, and Antioxidants: Back and Forth in the Pathophysiology of Chronic Diseases. Front Physiol., 2020; 11(694): 1-21.

111. Shin YH, Yu J, Kim KW, Ahn K, Hong SA, Lee E, Yang SI, Jung YH, Kim HY, Seo JH, Association between cord blood 25-hydroxyvitamin D concentrations and respiratory tract infections in the first 6 months of age in a Korean population: a birth cohort study (COCOA). Korean J Pediat., 2013; 56(10): 439-445.

112. Sifaki M, Calina D, Docea AO, Tsioumas S, Katsarou MS, Papadogiorgaki S, Fragkiadaki P, Branisteanu DE, Kouskoukis K, Tsiaoussis J, A novel approach regarding the anti-aging of facial skin through collagen reorganization. Experim Therap Med., 2020; 19(1): 717-721.

113. Spiro A, Buttriss JL, Vitamin D: An overview of vitamin D status and intake in Europe. Nutr Bull., 2014; 39(4): 322-350.

114. Suceveanu AI, Mazilu L, Suceveanu AP, Parepa I, Dumitrescu IB, Dragoi CM, Nicolae AC, Botea F, Voinea F, Burcea-Dragomiroiu GTA, Assertion for montelukast in the covid-19 pandemics?. Farmacia, 2020; 68(4): 579-585.

115. Techarang T, Sricharoenvej S, Lanlua P, Niyomchan A, Chookliang A, Plaengrit K, Baimai S, Long-Term Effects of Diabetes Mellitus on Skin Melanocytes in Rats. J Tech Soc Sci., 2017; 1(3): 56-61.

116. Thangavel RR, Bouvier NM, Animal models for influenza virus pathogenesis, transmission, and immunology. J Immunol Methods, 2014; 410: 60-79.

117. Torequl Islam M, Nasiruddin M, Khan IN, Mishra SK, Kudrat EZM, Alam Riaz T, Ali ES, Rahman MS, Mubarak MS, Martorell M, Cho WC, Calina D, Docea
AO, Sharifi-Rad J, A Perspective on Emerging Therapeutic Interventions for COVID-19. Front Public Health., 2020; 8(281): 1-15.

118. Trump DL, Aragon-Ching JB, Vitamin D in prostate cancer. Asian J Androl., 2018; 20(3): 244-252.

119. Tsatsakis A, Calina D, Falzone L, Petrakis D, Mitrut R, Siokas V, Pennisi M, Lanza G, Libra M, Doukas SG, Doukas PG, Kavali L, Bukhari A, Gadiparthi C, Vageli DP, Kofteridis DP, Spandidos DA, Paoliello MMB, Aschner M, Docea AO, SARS-CoV-2 pathophysiology and its clinical implications: An integrative overview of the pharmacotherapeutic management of COVID-19. Food Chem Tox., 2020; 146: 111769, doi: 10.1016/j.fct.2020.111769.

120. Uro M, Beauchet O, Cherif M, Graffe A, Milea D, Annweiler C, Age-related vitamin D deficiency is associated with reduced macular ganglion cell complex: a cross-sectional high-definition optical coherence tomography study. PLoS One, 2015; 10(6): 1-12.

121. Wang KH, Lin RD, Hsu FL, Huang YH, Chang HC, Huang CY, Lee MH, Cosmetic applications of selected traditional Chinese herbal medicines. $J$ Ethnopharmacol., 2006; 106(3): 353-359.

122. Wang W, McKinnie SM, Farhan M, Paul M, McDonald T, McLean B, Llorens-Cortes C, Hazra S, Murray AG, Vederas JC, Angiotensin-converting enzyme 2 metabolizes and partially inactivates pyr-apelin-13 and apelin-17: physiological effects in the cardiovascular system. Hypertension, 2016; 68(2): 365-377.

123. Wu C, Liu Y, Yang Y, Zhang P, Zhong W, Wang Y, Wang Q, Xu Y, Li M, Li X, Zheng M, Chen L, Li H, Analysis of therapeutic targets for SARS-CoV-2 and discovery of potential drugs by computational methods. Acta Pharm Sin B., 2020; 10(5): 766-788.

124. Xu J, Yang J, Chen J, Luo Q, Zhang Q, Zhang H, Vitamin D alleviates lipopolysaccharideinduced acute lung injury via regulation of the reninangiotensin system. Mol Med Rep., 2017; 16(5): 7432-7438.

125. Zaim S, Chong JH, Sankaranarayanan V, Harky A, COVID-19 and Multiorgan Response. Curr Probl Cardiol., 2020: 100618, doi: 10.1016/j.cpcardiol.2020.100618.

126. Zhou YF, Luo BA, Qin LL, The association between vitamin D deficiency and community-acquired pneumonia: A meta-analysis of observational studies. Medicine, 2019; 98(38): 1-7.

127. Zisi D, Challa A, Makis A, The association between vitamin $\mathrm{D}$ status and infectious diseases of the respiratory system in infancy and childhood. Hormones, 2019; 18(4): 353-363.

128. Zittermann A, Pilz S, Hoffmann H, Marz W, Vitamin D and airway infections: a European perspective. Eur J Med Res., 2016; 21(1): 1-10. 